\title{
THE EXPERIMETAL INVESTIGATION OF EVAPORATOR'S CONDITION ON PERFORMANCE OF REFRIGERATION SYSTEMS
}

\begin{abstract}
E. J. C. Cavalcanti
University of Rio Grande do Norte Department of Mechanical Engineering Lagoa Nova, S/N, Natal, Rio Grande do Norte, Brazil. educanti@ufrnet.br

ABSTRACT

Due to the heat and mass transfer characteristics, the cooling and dehumidifying processes of evaporator are complex. In this sense, the present paper details the heat and mass transfer coefficients of moist air over surfaces for different cooling mode: dry, wet and partially wet. A modeling of the classical evaporator was reviewed by using finned surfaces wavy correlations for air-side. The mode of cooling was determined through a latent air-side convective heat transfer coefficient by correlating the experimental data with the model. In the literature have values of fouling factor for oil-bearing refrigerant and a fouling factor for air side coefficients for evaporator in operation for five years. The results have shown new values for these coefficients for evaporator in operation for eight years identifying a reduction of the nominal refrigeration capacity.
\end{abstract}

Keywords: Refrigerating unit,R22, Evaporator, modeling.

\section{INTRODUCTION}

Evaporators are extensively found in the airconditioning, heating, and refrigeration systems. The finned-tube evaporator is one of the most available device. The effect of an evaporator condition was evaluated in a Brazilian household air-conditioning with nominal cooling capacity of 10,000 BTU.h-1 $(2.930 \mathrm{~kW})$.

Experimental data were obtained in a conventional wavy fin evaporator operating with R22 refrigerant. The dominating thermal resistance is on the air-side (Wang et al, 1999). Extensive correlations for the air-side heat transfer, mass transfer, and pressure loss and for the refrigerant side heat transfer and pressure loss for two-phase and superheated were developed with good accuracy (Seker at al. 2004). In air side, correlations account for the thermal resistance of a wetted coil obtained by the convective heat transfer and mass transfer or phase change of the water vapor. The air is dehumidified and the heat transfer is increased.

However there are few papers dealing with investigation on fouling factor for oil-bearing refrigerant and air-side fouling factor. Rosenhow et al (1985) determined theses fouling factors values used in the numerical models for a five years old evaporator coil.

Many air-conditioning are more than five years old, and most of the models from literature are not able to predict their performance due the new thermal resistance.

In this paper it is presented an experimental investigation of thermal resistances of an evaporator
- that is eight years old. The main contribution is to evaluate the effect of the evaporator fin dust deposition and crumpling fin, isolately and in combination of the two.

\section{EXPERIMENTAL APPARATUS}

In order to evaluate the performance of the refrigeration system it was employed an instrumented conventional air conditioning system of the mark Springer Carrier model 51JQB010-B-761-62, supply voltage of $220 \mathrm{~V}$ with rated current of $8.5 \mathrm{~A}$ and nominal flow the air on evaporator of $495 \mathrm{~m}^{3} . \mathrm{h}-1$ $\left(0.1375 \mathrm{~m}^{3} . \mathrm{s}-1\right)$.

The temperature and pressure of refrigerant $\mathrm{R}-22$ were measured with Bourdon manometer and type $\mathrm{K}$ thermocouples. The thermocouples were set on the external wall of the tube. Sporket (2001) found that the temperature of the refrigerant is the same as the wall of the copper tubing. The thermocouples were isolated to prevent the condensation of water's steam from the moist air.

The cooling capacity was estimated for enthalpy and mass flow of moist air. The dry-bulb and wetbulb temperatures were used to evaluate the enthalpy of moist air. The volumetric air flow was measured by vane anemometer. The mass flow rate of refrigerant was estimated by equaling the cooling capacity of air side.

The power consumption of the compressor and the fan was estimated through the analysis of voltage and current measured using a digital wattmeter. The description of instruments used on the experiment has been seen in Table 1. 
Table 1. Characteristics of Instruments for Measures.

\begin{tabular}{|c|c|}
\hline Instruments & Desc \\
\hline therm & $\begin{array}{l}\text { Tipo K, range }-40{ }^{\circ} \mathrm{C} \text { a } 204{ }^{\circ} \mathrm{C} \text {, } \\
\text { accuracy } \pm 1.0^{\circ} \mathrm{C} \text {, resolution } 1.0^{\circ} \mathrm{C}\end{array}$ \\
\hline $\begin{array}{l}\text { Digital } \\
\text { Temperature } \\
\text { Indicator }\end{array}$ & $\begin{array}{l}\text { Coel, model CLCD2, range }-50{ }^{\circ} \mathrm{C} \text { a } \\
50{ }^{\circ} \mathrm{C} \text {, accuracy } \pm 0.6^{\circ} \mathrm{C} \text {, resolution } \\
0.1^{\circ} \mathrm{C}\end{array}$ \\
\hline $\begin{array}{l}\text { Digital } \\
\text { meter }\end{array}$ & $\begin{array}{l}\text { Minipa, model ET-4090, } \\
\text { Current: Accuracy 0 1000A } \pm \\
(6.0 \%+10 \mathrm{D}) \text {, Resolution: } 0.1 \mathrm{~A} . \\
\text { Voltage: Accuracy: } \pm(1.0 \%+5 \mathrm{D}) \text {; } \\
\text { Resolution: } 0.1 \mathrm{~V}\end{array}$ \\
\hline $\begin{array}{l}\text { Bour } \\
\text { manc }\end{array}$ & $\begin{array}{l}\text { Gitta, high pressure Gauge, }-30 \text { a } \\
120 \text { psi }(-207 \mathrm{a} \text { 827 } \mathrm{kPa}) \text {, resolution } \\
1 \mathrm{psi}(6.9 \mathrm{kPa}) \text {, accuracy } 6.9 \mathrm{kPa} \text {. } \\
\text { low pressure Gauge, } 0-500 \mathrm{psi}(0- \\
3450 \mathrm{kPa}) \text {, resolution } 5 \mathrm{psi}(34.5 \\
\mathrm{kPa})\end{array}$ \\
\hline $\begin{array}{l}\text { Digital vane } \\
\text { anemometer }\end{array}$ & 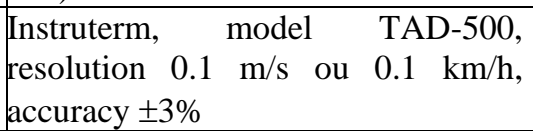 \\
\hline
\end{tabular}

The tube evaporator was made of cooper and the fins were made of aluminum. The characteristics of evaporator are show in Table 2.

Table 2. Characteristics of Evaporator.

\begin{tabular}{|c|c|}
\hline $\mathrm{D}_{\text {ext }}$ external tube diameter & $11.44 \times 10^{-3} \mathrm{~m}$ \\
\hline $\mathrm{D}_{\text {int }}$ internal tube diameter & $8 \times 10^{-3} \mathrm{~m}$ \\
\hline $\mathrm{D}_{\mathrm{c}}$ fin collar outside diameter & $11.80 \times 10^{-3} \mathrm{~m}$ \\
\hline $\mathrm{F}_{\mathrm{p}}$ fin Pitch & $1.68 \times 10^{-3} \mathrm{~m}$ \\
\hline $\mathrm{L}$ length of evaporator $[\mathrm{m}]$ & $0.393 \mathrm{~m}$ \\
\hline $\mathrm{N}$ number of longitudinal tube row & 3 \\
\hline $\mathrm{P}_{\mathrm{l}}$ longitudinal tube pitch & $14.48 \times 10^{-3} \mathrm{~m}$ \\
\hline $\mathrm{P}_{\mathrm{t}}$ transverse tube pitch & $24.06 \times 10^{-3} \mathrm{~m}$ \\
\hline
\end{tabular}

\section{Correction of Wet bulb Temperature}

The wet-bulb thermometer is one of the most devices for humidity measurement; however, it shall bear in mind that in order to be a realiable instrument, the psycrometer wet-bulb temperature must be correlated with the thermodynamic wet-bulb temperature. The process on moistened bulbs (wetbulb thermometer) is influenced by heat and mass transfer. When the psychrometer is exposed to a moving stream of moist air, the evaporation of water and the convection heat transfer occurs. This process depends on the velocity of the air flow that arrives the steady state for the rate of heat and mass transfer. In fact, the thermodynamic wet-bulb temperature does not depend on the velocity of the flow. The wetbulb air temperature of input and output of evaporator was corrected for the thermodynamic wetbulb temperature according to the correlation of Threlkeld (1970). In process wet bulb thermometer at the steady state, the cooling heat of evaporated water is equal as the convection heat transfer from the air steam more radiation heat transfer from surrounding surfaces. The energy balance is:
$h_{D} \cdot\left(W_{s, w b}-W\right) \cdot h_{f g, w b}=h_{c} \cdot\left(T-T_{w b}\right)+h_{R} \cdot\left(T_{s u r}-T_{w b}\right)$

or

$$
\mathrm{W}=\mathrm{W}_{\mathrm{s}, \mathrm{wb}}-\mathrm{K} \cdot\left(\mathrm{T}-\mathrm{T}_{\mathrm{wb}}\right)
$$

where

$$
K=\frac{L e \cdot c_{P, a}}{h_{f g, w b}}\left[1+\frac{h_{R}\left(T_{\text {sur }}-T_{w b}\right)}{h_{c}\left(T-T_{w b}\right)}\right]
$$

W ... humidity ratio of thermodynamic wet-bulb temperature, $\mathrm{T}$... moist air temperature, $\mathrm{h}_{\mathrm{fg}, \mathrm{wb}} \ldots$ condensation enthalpy of water, $h_{c} \ldots$ coefficient of convection forced at cylinder, $h_{R} \ldots$ coefficient of radiation, subscript: s,wb ... wet bulb surface, sur ... surroundings.

The straight-line law shows that when air is transferring heat and mass (water) to or from a wetted surface, the air condition leads toward to the saturation line at the average fin surface temperature, (Stoecker and Jones, 1985). The line between points 1 and 2 indicates the average surface temperature, see Fig. 2. If the wet-bulb temperature is not corrected, some tests do not lead to the temperature of averaged fin surface made by the straight-line in a psychometric chart.

The experimental procedure was established on a three conditions basis. In the first experimental, the air-conditioning was dust, the evaporator's fin had fouling and was crumpled. The second experiment: the air-conditioning was washed and the fins were cleaned and crumpled. Finally, in the last experiment: the evaporator's fins were cleaned and decrumpled.

The experimental runs were made to determine the refrigeration capacity, air dew temperature, around fin temperature to estimate the cooling mode, Global heat coefficient (UA), mass flow rate of refrigerant, fouling coefficient for oil-bearing refrigerant, external thermal resistance, dry and wet convective coefficient and air-side fouling coefficient.

\section{MODEL}

The thermal resistance and coefficient of heat transfer and fouling were determinated by a model. The refrigeration capacity was determinated by the wet-buld and dry-bulb temperature. The temperature difference between the refrigerant and the cooling fluid is represented by the LMTD (log mean temperature difference), considering constant the temperature of refrigerant. Although the temperature difference is higher, the result provides has reasonable accuracy.

The total thermal resistance comprised the resistance of air, air-side fouling, tube, fin-to-tube contact, refrigerant-side fouling and refrigerant. The system model takes into account each one of the 
thermal resistances. The following equation represents the heat transfer rate.

$$
q=\frac{1}{\frac{1}{\left(h_{a}+h_{\text {lat }}\right) A \cdot \eta_{s}}+\frac{1}{h_{f, a} \cdot A \cdot \eta_{s}}+\frac{1}{R_{\text {cont }} A_{\text {tont }}}+\frac{1}{2 k \cdot \pi \cdot L} \ln \frac{D_{\text {ext }}}{D_{\mathrm{nt}}}+\frac{1}{h_{f, \mathrm{int}} A_{\mathrm{nt}}}+\frac{1}{h_{\mathrm{nt}} A_{\mathrm{nt}}}}
$$

Where: $h_{a}$ is the convective heat transfer coefficient [W.m-2K-1]; $h_{\text {lat }}$ is the latent heat transfer coefficient [W.m-2K-1]; $\eta_{\mathrm{s}}$ is the surface efficiency, $A_{t}$ is the total air side surface area $\left[\mathrm{m}^{2}\right] ; h_{f, a}$ is the air side fouling factor [W.m-2K-1]; $\mathrm{R}_{\text {cont }}$ is the contact conductance [W.m-2K-1]; $\mathrm{k}$ is the tube heat conductivity [W.m-1K-1]; $\mathrm{A}_{\text {cont }}$ is the contact interference area $\left[\mathrm{m}^{2}\right] ; \mathrm{h}_{\mathrm{f} \text {,int }}$ is the refrigerant side fouling factor [W.m-2K-1]; $A_{\text {int }}$ is the tube inside surface area $\left[\mathrm{m}^{2}\right] ; \mathrm{h}_{\mathrm{int}}$ is the boiling heat transfer coefficient [W.m-2K-1].

The convective heat transfer coefficient for the air side of the evaporator may be evaluated according to the Colburn factor (j) for wavy fin configuration by the correlation of Wang et al. (1999):

$$
j=\frac{N u}{\operatorname{Re} \cdot \operatorname{Pr}^{1 / 3}}=0,324 \cdot \operatorname{Re}_{D c}^{j 1}\left(\frac{F_{p}}{P_{l}}\right)^{j 2}(\tan \theta)^{j 3}\left(\frac{P_{l}}{P_{t}}\right)^{j 4} N^{0,428}
$$

Where: $\mathrm{Re}_{\mathrm{DC}}$ is the Reynolds number based on tube collar diameter $\left(D_{c}\right.$ is the fin collar outside diameter $\mathrm{D}_{\mathrm{o}}+2 . \delta_{\mathrm{f}}$ ); $\delta_{\mathrm{f}}$ is the fin thickness $[\mathrm{m}] ; F_{P}$ is fin pinch $[\mathrm{m}] ; P_{l}$ is the longitudinal tube pinch $[\mathrm{m}] ; \mathrm{P}_{\mathrm{t}}$ is the transverse tube pinch $[\mathrm{m}] ; N$ is the row number; $j_{1,2,3,4}$ are constants.

The dehumidification of air is associated with the latent air-side convective heat transfer coefficient. The effect of air dehumidification is to increase in the heat transfer by the change of phase of water vapor. The latent heat transfer can be expressed by the Lewis number (Le) and the sensible heat transfer coefficient $\left(\mathrm{h}_{\mathrm{a}}\right)$ [W.m-2K-1]:

$$
\begin{gathered}
h_{\text {lat }}=\frac{h_{a} \cdot i_{w} \cdot C}{L e \cdot C_{p, d a}} \\
C=\frac{w_{a}-w_{s, \min }}{T_{a}-T_{s, \min }}
\end{gathered}
$$

Where: $i_{w}$ is the condensation heat of water; $C_{p, d a}$ is the specific heat of dry air. Parameter $\mathrm{C}$ is the rate of the difference of specific humidity at air temperature $\left(\mathrm{T}_{\mathrm{a}}\right)$ and saturation specific humidity at fin condensate surface temperature $\left(\mathrm{T}_{\mathrm{s}, \mathrm{min}}\right)$ by the difference of temperature respective.

\section{Cooling mode}

The evaluation of the cooling model was made comparing the air dew temperature with the temperature around fin. It is important discern the method of cooling to evaluate the latent coefficients on the air-side. Wang and Hihara, (2003) show three modes of cooling defined for the temperature when moist air is cooled over a finned tube surface. For an inlet state, when:

1. The dew point temperature is equal to, or less than the tube outer surface temperature $\mathrm{T}_{\text {adew }} \leq \mathrm{T}_{\text {bo }}$. Process totally dry.

2. The dew temperature is equal to, or greater than the fin tip temperature, $T_{\text {adew }} \geq T_{\text {ftíp }}$. Process totally wet.

3. The dew temperature is between the fin tip temperature and the fin base temperature, $\mathrm{T}_{\text {ftíp }}>\mathrm{T}_{\text {adew }}$ $>\mathrm{T}_{\text {bo }}$. Process partially wet with two distinct processes:

a) When $T_{\text {ftíp }}>T_{\text {adew }}>T_{\text {avf }}$, Process with net vapor condensate.

b) When $T_{\text {avf }} \geq T_{\text {adew }}>T_{\text {ftíp }}$, Process without net vapor condensate.

The modes of cooling of a moist air were showed in Fig. 1.

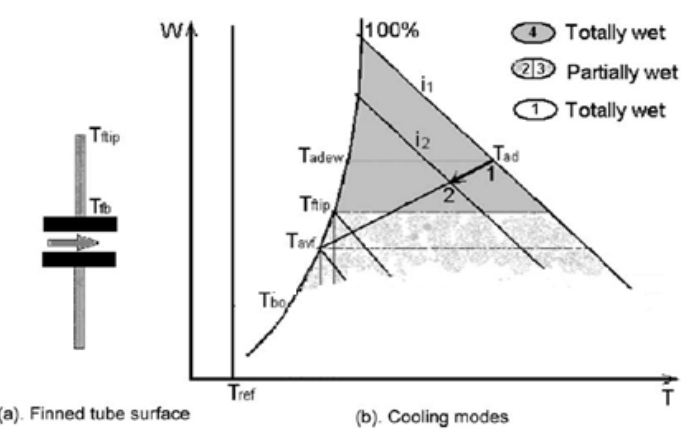

Figure 1. Cooling mode of a moist air over a finnedtube surface. Source (Wang and Hihara, 2003).

The average fin surface temperature in model can be expressed as:

$$
q=\eta_{s} \cdot h \cdot A_{t} \cdot \frac{\left(T_{a 1}-T_{a 2}\right)}{\ln \left[\frac{T_{a 1}-T_{r e f}}{T_{a 2}-T_{r e f}}\right]}=h \cdot A_{t} \cdot \frac{\left(T_{a 1}-T_{a 2}\right)}{\ln \left[\frac{T_{a 1}-T_{a v f}}{T_{a 2}-T_{a v f}}\right]}
$$

The heat transfer from air to refrigerant is the main function of evaporator operates. So, the heat transfer rate may be identified with various thermal resistances. Extensive investigation has been proposed for a modeling of dry coils. Relatively, researches on the cooling and dehumidifying coils are limited due to the complication of simultaneous heat and mass transport of moist air to cooled fin surfaces, (Oskarsson et al; 1990), (Wang and Hihara, 2003).

The fouling factor values proposed by Rosenhow et al. (1985), apud (Oskarsson at al., 1990) for the five year old evaporator coil for oil-bearing refrigerant vapors is $2.84 \mathrm{~kW} \cdot \mathrm{m}-2 \mathrm{~K}-1$ and for airside fouling factor operation in industrial air is 2.84 $\mathrm{kW} \cdot \mathrm{m}-2 \mathrm{~K}-1$. The fouling factor coefficient for 
evaporators in operation for eight years was made by the comparative analysis of the experimental data.

The Contact resistance appears when the heat is exchanged across an interface where two surfaces are in imperfect contact. The contact resistance between the tube and the fin is determined from the contact interference area and contact conductance. Wang e Chi (2000) determinate that the range of contact conductance is 11.0 to $16.0 \mathrm{~kW} \cdot \mathrm{m}-2 \mathrm{~K}-1$. On the other hand, Wang et al. (2000) show this parameter from range of 10.0 to $15.0 \mathrm{~kW} \cdot \mathrm{m}-2 \mathrm{~K}-1$. In the present paper was used the mean value of 13.0 $\mathrm{kW} \cdot \mathrm{m}-2 \mathrm{~K}-1$ and contact area was the same as the external tube area.

The heat transfer process on the refrigerant side has to be considered in two regions. The first one is the two-phase region and the second one is the superheated region. The heat transfer aspects of twofase are involved because of a combination of liquid and vapor refrigerant exists in the tube of evaporators and condensers. Altman et al. (1960) presented average coefficients for R-22 evaporating at temperatures from 4.4 to $26.7^{\circ} \mathrm{C}$ in a tube diameter $8.7 \mathrm{~mm}$ on 2,4 m long. Coefficients were determined for approximately $15 \%$ vapor quality changes. The range investigated was $x=0.20$ to superheat.

$$
\begin{gathered}
\frac{\mathrm{h}_{\mathrm{int}} \cdot \mathrm{D}_{\mathrm{int}}}{\mathrm{k}}=0,0225 \cdot\left[\mathrm{Re}^{2} \cdot \mathrm{Kf}\right]^{0,375} \\
\mathrm{Kf}=\frac{\Delta \mathrm{x} \cdot \mathrm{i}_{\mathrm{lv}}}{\Delta \mathrm{L} \cdot \mathrm{g}}
\end{gathered}
$$

Where: $\mathrm{Kf}$ is the boiling number; $\Delta \mathrm{x}$ is difference refrigerant quality; $i_{l v}$ is the condensation refrigerant enthalpy; $\Delta \mathrm{L}$ is the section length; $\mathrm{g}$ is gravity.

The heat transfer average coefficients for refrigerant on superheated process are estimated by Dittus-Bolter correlation applicable to turbulent flow in a circular tube.

\section{Determination of the Thermal Resistance}

The thermal oil resistance reduces the heat transfer inside the tube. The effect of oil was determinated by the thermal resistance.

$$
q=\frac{T_{b o}-T_{4(s a t)}}{\frac{1}{R_{\text {cont }} A_{\text {cont }}}+\frac{1}{2 \cdot k \cdot \pi \cdot L} \ln \frac{D_{e x t}}{D_{\mathrm{int}}}+\frac{1}{h_{f, \text { int }} \cdot A_{\mathrm{nt}}}+\frac{1}{h_{\mathrm{int}} \cdot A_{\mathrm{nnt}}}}
$$

The tube temperature $\left(\mathrm{T}_{\mathrm{bo}}\right)$ was determinated using the equation (8):

$$
T_{a v g}-T_{a}=\eta_{e x t} \cdot\left(T_{b o}-T_{a}\right)
$$

There is in air side the fouling factor that was estimated by the equation (4).
The resistance of air side fouling factor was determinate by the difference. This term may be composed for the fouling's dust and the fin's crumpled.

\section{RESULTS AND DISCUSSION}

The tests were driven to investigate the evaporator performance. After reaching a steady state condition, a set of data was taken such as pressure, temperature of refrigerant, wet bulb and dry bulb temperature of air, the velocity of flow air inlet and outlet evaporator.

Three test conditions runs were made: The air conditioning with fouling and crumpled, with fouling and decrumpled, and clear and decrumpled. Ten replications were made for each test conditions at different air temperature. The experimental measurements of the air temperature in and out of the evaporator allowed estimating the average fin surface temperature.

In all experimental data were determinated the media's error by Student's distribution (t) and Standart deviations (s) with $90 \%$ of confiability.

$$
E=s . t \sqrt{(n)}
$$

The data of air mass flow were estimated equalizing the heat transfer of air with the heat transfer of refrigerant inside the tube. The air volume flow was measured with vane anemometer. The refrigerant mass flow and the experimental data of Air volume flow for the three conditions with error may be found in Table 3 and Table 4, respectively.

Table 3. Experimental Data of Refrigerant Mass Flow.

\begin{tabular}{|l|c|c|c|}
\hline $\begin{array}{l}\text { refrigerant } \\
\text { mass flow }\end{array}$ & Foul/crump & Clear/decrump & Clear/crump \\
\hline $\begin{array}{l}\text { Mean } \\
{[\mathrm{kg} / \mathrm{h}]}\end{array}$ & 26.96 & 35.36 & 45.9 \\
\hline Error $[\mathrm{kg} / \mathrm{h}]$ & 3.07 & 6.37 & 3.37 \\
\hline $\begin{array}{l}\text { Maximum } \\
\text { limit }[\mathrm{kg} / \mathrm{h}]\end{array}$ & 30.03 & 41.73 & 49.27 \\
\hline $\begin{array}{l}\text { Minimum } \\
\text { limit }[\mathrm{kg} / \mathrm{h}]\end{array}$ & 23.90 & 28.99 & 42.53 \\
\hline
\end{tabular}

Table 4. Experimental Data of Air Volume Flow.

\begin{tabular}{|l|c|c|c|}
\hline $\begin{array}{l}\text { Air volume } \\
\text { flow }\end{array}$ & Foul/crump & Clear/decrump & Clear/crump \\
\hline $\begin{array}{l}\text { Mean } \\
{\left[\mathrm{m}^{3} / \mathrm{s}\right]}\end{array}$ & 360.5 & 398.0 & 364.5 \\
\hline $\begin{array}{l}\text { Error } \\
{\left[\mathrm{m}^{3} / \mathrm{s}\right]}\end{array}$ & 19.9 & 22.1 & 20.0 \\
\hline $\begin{array}{l}\text { Maximum } \\
\text { limit }\left[\mathrm{m}^{3} / \mathrm{s}\right]\end{array}$ & 380.4 & 420.1 & 384.5 \\
\hline $\begin{array}{l}\text { Minimum } \\
\text { limit }\left[\mathrm{m}^{3} / \mathrm{s}\right]\end{array}$ & 340.6 & 375.9 & 344.6 \\
\hline
\end{tabular}

The refrigerant mass flow is equal, since the limits are within the range of error. However there is a difference between the tests for Foul/crump and 
Clear/crump. In experimental data for the air flow are all equal. His experimental error does not produce a significant difference.

According to Stoecker (1985) there is a tendency of cooling capacity with the temperature of subcooling. The increasing the subcooling's temperature, increase the refrigerating effect and consequently increase the cooling capacity. Therefore the parameters were related to the temperature of subcooling.

The heat transfer of the evaporator (Refrigeration capacity) for the equation 4 for the three tests were showed in Fig. 2.

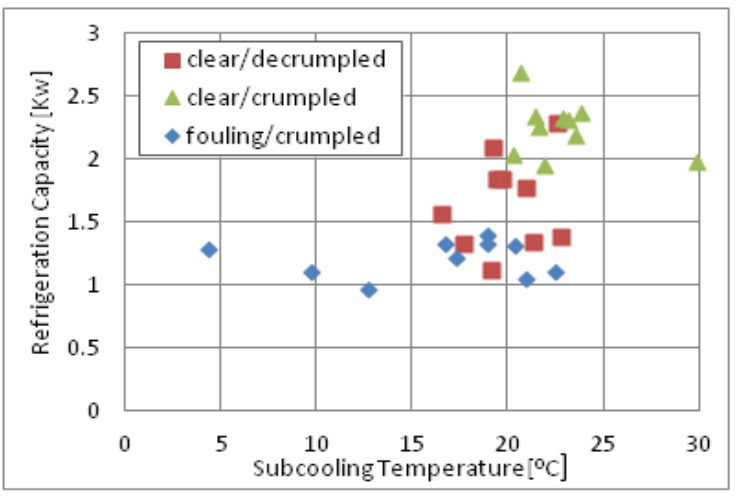

Figure 2. Refrigeration capacity versus subcooling temperature.

The overall heat transfer coefficient for evaporator also were analyzed. Their values for the three tests may be seen in Fig. 3.

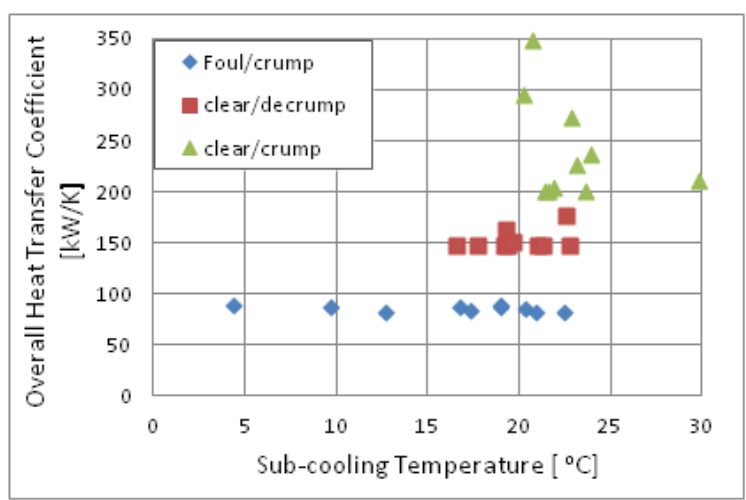

Figure 3. Overall heat transfer coefficient versus subcooling temperature.

The values of the the refrigeration capacity for the air conditioning fouling/crumpled are approximately linear. The refrigeration capacity is higher for cleaned apparatus. The presence of fouling reduces the refrigeration capacity and the overall heat transfer coefficient. There is not significant differences for the experiment data of clear/crump and clear/decrump conditions.

The overall transfer coefficient also is higher for system clear. However there is a significant difference at this parameter for the tests clear/crump and clear/decrump. The small reduction in the external area of air flow increases the convective coefficients of air.

The subcooling temperature is lower at test foul/crump, indicating that the refrigerating effect is lower. This was the worst condition's test with the low capacity of refrigeration.

It was noticed that there is a larger thermal resistance between the refrigerant and the internal tube surface. The thermal oil resistances inside the tube were estimated by the tube temperature using equation (12) and the thermal resistance involved at the equation (11). The experimental data of coefficient fouling factor $\left(\mathrm{h}_{\mathrm{f}, \text { int }}\right)$ may be seen in the Table 5.

Table 5. Experimental Data of Coefficient Fouling Factor Inside the Tube.

\begin{tabular}{|l|c|c|c|}
\hline Air vol flow & Foul/crump & Clear/decrump & Clear/crump \\
\hline $\begin{array}{l}\text { Mean } \\
{\left[\mathrm{W} /{ }^{\circ} \mathrm{C} \cdot \mathrm{m}^{2}\right]}\end{array}$ & 1156 & 1869 & 3109 \\
\hline $\begin{array}{l}\text { Error } \\
{\left[\mathrm{W} /{ }^{\circ} \mathrm{C} \cdot \mathrm{m}^{2}\right]}\end{array}$ & 304 & 872 & 727 \\
\hline $\begin{array}{l}\text { Maximum } \\
\text { limit } \\
{\left[\mathrm{W} /{ }^{\circ} \mathrm{C} \cdot \mathrm{m}^{2}\right]}\end{array}$ & 1459 & 2741 & 3837 \\
\hline $\begin{array}{l}\text { Minimum limi } \\
{\left[\mathrm{W} /{ }^{\circ} \mathrm{C} \cdot \mathrm{m}^{2}\right]}\end{array}$ & 852 & 996 & 2383 \\
\hline
\end{tabular}

The cooling mode influences the evaluation of the coefficient of convection. The cooling can occur totally dry, and with dehumidification of air in process totally wet and partially wet. To determine the cooling mode it is important the correct evaluation of the tube outer surface temperature $\left(\mathrm{T}_{\mathrm{bo}}\right)$, the fin tip temperature $\left(\mathrm{T}_{\mathrm{ftí}}\right)$ and the average fin surface temperature $\left(\mathrm{T}_{\text {avf }}\right)$ to compare with the dew point temperature of air inlet of the evaporator according to item3.2 Cooling mode. The evaluation of cooling capacity for the cooling mode appears in Fig. 4.

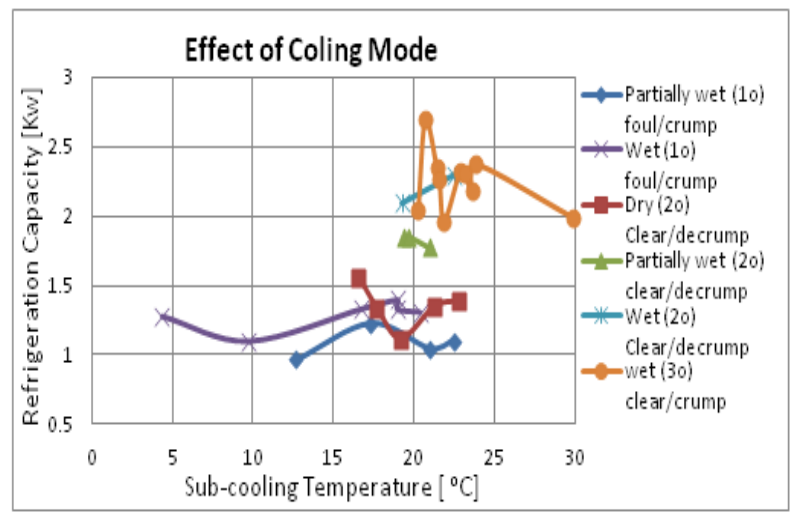

Figure 4. Effect of cooling mode versus fins condition's evaporator. 
In the first experiments (fins foul/crump), there were partially wet and totally wet for cooling mode, subsequently, at second tests (fins clear/decrump), there were the three cooling mode, and finally, at last tests, (fins clear/crump), there were only wet mode.

Analyzing all experiments with clear fins, it was observed that the refrigeration capacity is higher at partially wet cooling and worse at dry cooling. There is not a significant difference between the tests wet/clear/crump and wet/clear/decrump.

At the two experiments with fouling fins, it was observed that the refrigeration capacity is higher at wet cooling, after at partially wet cooling and worse at dry cooling. Theirs values are similar at dry cooling mode/clear decrumped. The effect of cooling mode and clear or fouling fins combine. Both are not isolated determinant.

The cooling mode is strongly affected for the wet of ambient air. It is preferable that the cooling systems to operate in wet environments due the reduction of thermal resistance of air side. The resistance of air side were terminated using the correlation (4), the coefficient fouling factor inside the tube it was used the mean value of Table (5). The thermal resistance existing at fin's evaporator was investigated as showed in Fig. 5.

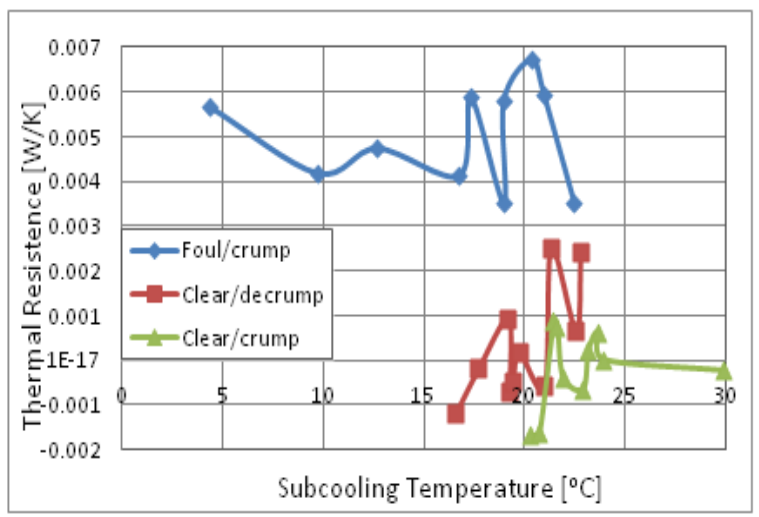

Figure 5. Thermal resistance at fin's evaporator.

There is a resistance well defined in fouling fin's evaporator (foul/crump), however, in the tests with clear/decrump and clear/crump, the resistance was being approximately equal a zero $(+0.000608$ and $0.000194 \mathrm{~K} . \mathrm{W}-1)$, respectively. The thermal resistance of both test indicated that there are not significant differences at crumpled or decrumpled fins. Their maximum and minimum values are in the same range. The foul/crump factor for air side are values mean 41.08 W.m-2K-1, error 10.17 W.m-2K1, maximum limit $51.24 \mathrm{~W} . \mathrm{m}-2 \mathrm{~K}-1$ and minimum limit $30.91 \mathrm{~W} \cdot \mathrm{m}-2 \mathrm{~K}-1$. The Table 6 indicates the thermal resistance for the three tests, their values mean, error, maximum and minimum limits divided for $10^{3}$.
Table 6. Experimental Data of Coefficient Fouling Factor Inside the Tube.

\begin{tabular}{|l|c|c|c|}
\hline $\begin{array}{l}\text { Thermal } \\
\text { resistance }\end{array}$ & Foul/crump & Clear/decrump & Clear/crump \\
\hline $\begin{array}{l}\text { Mean } \\
{\left[10^{3 \circ} \mathrm{C} / \mathrm{W}\right]}\end{array}$ & 5.02 & 0.608 & -0.194 \\
\hline $\begin{array}{l}\text { Error } \\
{\left[10^{3 \circ} \mathrm{C} / \mathrm{W}\right]}\end{array}$ & 0.81 & 1.53 & 0.650 \\
\hline $\begin{array}{l}\text { Maximum } \\
\text { limit } \\
{\left[10^{3 \circ} \mathrm{C} / \mathrm{W}\right]}\end{array}$ & 5.83 & 2.14 & 0.456 \\
\hline $\begin{array}{l}\text { Minimum } \\
\text { limit } \\
{\left[10^{3 \circ} \mathrm{C} / \mathrm{W}\right]}\end{array}$ & 4.21 & -0.92 & -0.844 \\
\hline
\end{tabular}

\section{CONCLUSION}

An experimental investigation on the effects of evaporator's condition on performance of refrigeration system has been conducted. The new value of the oil factor for refrigerant side and fouling factor for air side was estimated. The thermal oil resistances inside the tube reduce the evaporator's heat transfer.

There was an effect of cooling mode at refrigeration capacity. The refrigeration capacity depends strongly on fin's conditions, especially the fouling fin. The thermal resistance of fouling in test foul/crump is higher; in this manner, this fact reduces the refrigeration capacity and the overall heat transfer coefficient. The effect on fin's crumpled are not significant.

\section{REFERENCES}

Altman, M., Staub, F. W., and Norris, R. H., 1960, Local heat transfer and pressure drop for Refrigerant-22 condensing to horizontal tubes, Chemical Engineering Progress Symposium Series, Vol. 56, No. 30, pp. 151-60.

Oskarsson, S. P., Krakow, K. I.; and Lin, S., 1990, Evaporator models For Operation with Dry, Wet, and frosted finned surfaces. Part I: Heat Transfer and Fluid Flow Theory, ASHRAE Transactions, Vol. 96, Part 1.

Rosenhow, W. M., Hartnett, J. P., and Ganic, E. N., 1985, Handbook of Heat transfer Applications, 2d ed, New York, Mc Graw Hill.

Seker, D., Karatas, H., and Egrican, N., 2004, Frost Formation on Fin-and-Tube Heat Exchangers. Part II - Espermental Investigation of Frost Formation on Fin-Andtube Heat Exchangers, International Journal of refrigeration, Vol. 27, pp. 375-377.

Threlkeld, J. L. 1970, Thermal Enviromental Engineering, 2 ed. Englewood Cliffs, New Jersey: Prentice Hall Book Co.

Wang, C. C, Jang, J. Y., and Chiou, N. F., 1999, A Heat Transfer and Friction Correlation for Wavy Fin-and-Tube Heat Exchangers, International Journal of Heat and Mass transfer, Vol. 42, pp. 1919-1924. 
Wang, C. C., and Chi, K. Y., 2000, Heat Transfer and Friction Characteristics of Plain finand-tube Exchangers, Part I: New Experiemntal Data, International Journal of Heat and Mass Transfer, Vol. 43, pp. 2681-2691.

Wang, C. C., Chi, K. Y., and Chang, C. J., 2000, Heat Transfer and Friction Characteristics of Plain fin-and-tube Exchangers, Part II: Correlation, International Journal of Heat and Mass Transfer, Vol. 43, pp. 2693-2700.

Wang, J., and Hihara, E., 2003, Prediction of Air Coil Performance Under Partially Wet and Totally Wet Cooling Conditions Using Equivalent Dry-Bulb Temperature Method, International Journal of Refrigeration, Vol. 26, pp. 293-301.

Received: September 27, 2012

Revised: October 27, 2012

Accepted: November 27, 2012 